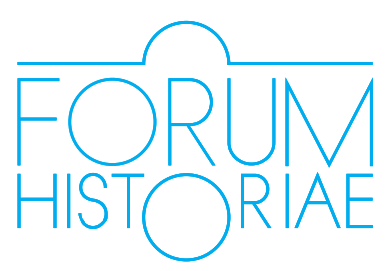

\title{
Úteky, vyhnanci a renegáti na moravsko-bavorskom pohraničí v 9. storočí
}

\author{
Matej Harvát
}

\begin{abstract}
HARVÁT, Matej: Fugitives, Exiles and Renegades on the Moravian and Bavarian Borderlands in the 9th Century.

The early medieval juridical norms commonly outlawed and, consequently, banished people convicted of serious crimes like murder, adultery or woman kidnapping. In the case of the ruling authority, monarchs punished the acts of treason and infidelity mainly with exile. Sources referring to the Moravian principality in the 9th century often mention exiles and fugitives from the higher social strata. The article provides a specification of these persons and a partial analysis of the political circumstances motivating the banishments and requests for asylum in the Moravian principality. Besides the remarkable case of Pribina, who was sent to exile by the Moravian prince Mojmír, almost every known exile and outcast came to the realm of the Moravians from the Carolingian Eastern March (Marcha orientalis). Therefore, the paper addresses the politics of exile on the Slavic and Bavarian borderlands near the Middle Danube and attempts to clarify the occurrence of Wilhelminer and, partly, of the Mojmirid outcasts.
\end{abstract}

Keywords: Great Moravia, Moravians, exiles, Wilhelminids, Eastern March

DOI: https://doi.org/10.31577/forhist.2019.13.2.3

$E^{n}$ urópsky včasný stredovek možno s istou dávkou zovšeobecnenia charakterizovat' ako obdobie postupného etablovania monarchickej moci. Formovanie král’ovstiev na územiach, ktoré počas antiky netvorili súčast' Rímskej ríše, ale naopak patrili do geografického priestoru barbarika, bolo zásadne ovplyvnené prenikaním nových politických vzorov a mocenských inštitúcií do sveta archaických kolektivistických spoločenstiev. „Barbarské“ germánske a slovanské populácie dlhé obdobie nezverovali hierarchicky najvyššiu mocenskú pozíciu výlučne jedinému dedičnému vládcovi. Takzvaní germánski králi síce predstavovali najmocnejších reprezentantov kmeňových spoločenstiev, ich postavenie však prinajmenšom do začiatku 9. storočia ešte nezodpovedalo charakteru dedičnej monarchie dynastického typu. ${ }^{1} \mathrm{~V}$ bádaní o „postrímskom“ či „barbarskom“ tradičnom zriadení sa všeobecne hovorí o špecifickej forme vojenského vodcovstva, ktorú v germánskych spoločnostiach reprezentovali takzvané kmeňové královstvá. ${ }^{2}$ Král'ovská hodnost'

\footnotetext{
* Táto práca bola podporená agentúrou VEGA v rámci projektu:VEGA2/0129/18: Panovnícka mocv stredoveku. Vývoj panovníckej moci od vel'komoravských kniežat po uhorských král'ov neskorého stredoveku.

1 WALLACE-HADRILL, John M. Early Germanic Kingship in England and on the Continent. Oxford : Oxford University Press, 1971, s. 124-151. Porovnaj: BYSTRICKÝ, Peter. Královská hodnost' u Germánov. In Forum Historiae, 2014, roč. 8, č. 2, s. 45-70; STEINHÜBEL, Ján. Slovanské "gentes" a ich vladykovia, kniežatá a kagani od st'ahovania národov po Svätopluka. In KOVÁĆ, Dušan a kol. (eds.) Slovenské dejiny v dejinách Európy. Vybrané kapitoly. Bratislava : Veda, 2015, s. 264-269.

2 WENSKUS, Reinhard. Stammesbildung und Verfassung: Das Werden der frühmitellalterlichen gentes. Graz : Böhlau Verlag, 1961, s. 576-582. K prelínaniu rímskych a germánskych tradícií vodcovstva a královstva pozri: WOLFRAM, Herwig. The Shaping of the Early Medieval Kingdom. In Viator : Medieval and Renaissance
} 
bola v podmienkach včasnostredovekých teritoriálnych zoskupení a politicko-etnických celkov (gentes) inštitucionálne nóvum, implementované až v dôsledku kontaktov s rímskym a krest’anským svetom. Moc a právomoci neskorších stredovekých patrilineárnych panovníkov výrazne presahovali staršie meritokratické postavenie kmeňových vodcov. Inými slovami, v mnohých európskych regiónoch až do 9. - 11. storočia panovník skôr viedol než vládol. ${ }^{3}$

Na rozdiel od centralizovanejších oblastí karolínskeho Západu či byzantského východného Stredomoria, politické zoskupenia stredovýchodnej Európy determinovali z hladiska mocensko-správneho usporiadania odlišné historické predpoklady. Špecifickost' stredoeurópskych pomerov bola príčinou skutočnosti, že koncentrácia moci v rukách tunajších dedičných monarchov nastala až okolo roku 1000. Najvplyvnejšie rody Arpádovcov, Přemyslovcov a Piastovcov počas 10. - 11. storočia natol'ko upevnili svoje spoločenské postavenie, že kniežacia, respektíve král'ovská moc zostala po nasledujúce storočia výsostnou doménou pokrvných príbuzných, ktorí svoj vladársky status legitimizovali prostredníctvom prináležitosti $\mathrm{k}$ dynastickej línii. ${ }^{4} \mathrm{~V}$ prípade výskytu odstredivých mocenských tendencií a vnútorných politických konfliktov, pokúšajúcich sa narušit’ panovníkom garantovaný vládcovský systém, využívali reprezentanti panovníckych rodov rozmanité prostriedky na presadzovanie zvrchovanej pozície. Jedným z dôležitých represívnych nástrojov, ktorý našiel miesto v právnej praxi európskych monarchií - a ešte skôr v barbarských zákonníkoch z 5. - 9. storočia - bol inštitút vyhnania do exilu.

Vyhnanstvo ako forma trestu bolo široko uplatňované od antiky až do moderných čias. ${ }^{5}$ Počas včasného stredoveku slúžilo vyháňanie do exilu na sankcionovanie neakceptovaného konania, preto boli nezriedka z komunity právne vylúčení jedinci usvedčení z obzvlášt' závažných prečinov. Išlo najmä o vraždu, cudzoložstvo, unesenie snúbenice, ale aj zabitie v nutnej obrane. V prvej tretine 9. storočia cisár L’udovít Pobožný aktualizoval staršie kodifikácie franského práva (Pactus legis Salicae) a vydal nové právne nariadenia, ktoré stanovovali vyobcovanie do vyhnanstva predovšetkým ako trest za úmyselné zabitie a únos cudzej snúbenice. ${ }^{6}$ Nútený exil bol tiež zvyčajným postihom za rebéliu proti panovníckej autorite, a to najmä v prípade, že na previnilcoch nebol uplatnený rovno hrdelný trest alebo iná

Studies, 1970, roč. 1 , s. 11-20.

3 MODZELEWSKI, Karol. Barbarská Evropa, Praha : Argo, 2017, s. 314-332; WOLFRAM, Herwig. Frühes Königtum. In ERKENS, Franz-Reiner (ed.) Das frühmittelalterliche Königtum, Ideelle und religiöse Grundlagen. Berlin; New York : Walter de Gruyter, 2005, s. 42-64, obzvlášt' 44-48, 55-56.

4 Súhrnne pre Čechy, Uhorsko a Pol'sko pozri: BEREND, Nora - URBAŃCZYK, PrzemysŁaw - WISEWSKI, Przemysław. Central Europe in the High Middle Ages. Bohemia, Hungary and Poland c. $900-$ c. 1300. Cambridge : Cambridge University Press, 2013, s. 165-211. Dobrý prehl'ad diskusie o dosahoch a limitoch panovníckej moci českých Přemyslovcov predstavuje: ŽEMLIČKA, Josef. Kníže a král v souřadnicích přemyslovského věku. In Český časopis historický, 2016, roč. 114, č. 1, s. 7-30.

5 K rozličným podobám vyhnanstva v stredoveku, ako aj k dobovým konceptualizáciám exilu a vyhnancov pozri: NAPRAN, Laura - VAN HOURS, Elisabeth (eds.). Exile in the Middle Ages, Selected Proceedings from the International Medieval Congress, University of Leeds, 8-11 July 2002 (d'alej Exile in the Middle Ages). Turnhou : Brepols, 2004.

6 Hludovici Pii Capitularia: Capitula legibus addenda a. 818, 136, §7, 9, 13. In Monumenta Germaniae Historica, (d'alej MGH) : Capitularia Regum Francorum I. (d'alej Capit. I.). BORETIVS, Alfredvs (ed.). Hannover : Hahniani, 1883, s. 282, 284. 
forma mocenskej deprivácie (oslepenie, kastrácia, poslanie do kláštora). Známym príkladom dobovej politickej praxe trestania prejavov odporu je zosadenie bavorského vojvodu Tassila III. v roku 788. Tohto agilolfingského panovníka po usvedčení z údajného spojenectva s Avarmi jeho suverén Karol Vel'ký omilostil. Tassilo nebol síce za svoje previnenie popravený, ale spoločne so synom Theodom museli odíst' do kláštora a vstúpit' do mníšskeho stavu (tonsoratus et in monasterio missus), čím ich rod stratil podiel na moci. ${ }^{7}$ Franský súd tiež rozhodol, že „Bavori, ktorí v nepriatel'stve proti pánu královi Karolovi chceli vytrvat', boli poslaní do vyhnanstva."8 Prax vypovedania do exilu zhrňuje aj životopis L'udovíta Pobožného, ked' spomína rozsudok nad odbojným obodritským kniežatom Slavomírom. Na dvore v Cáchach Slavomíra a jemu verných predákov obvinili z revolty proti cisárovi: „ten, ked’ bol obviňovaný zo vzbury a nijako sa nechcel bránit’ proti výčitkám, bol vypovedaný do vyhnanstva (exilo est deportatus)“.9 Doživotným vypudením bol teda zločinec alebo politický oponent navždy odstránený z komunity a nemohol sa podielat' na moci.

Vyhnanie však nemuselo byt' trvalé. Nezriedka mohlo slúžit' na dočasné vyobcovanie osoby alebo osôb, ktoré sa previnili voči platným právnym normám, prípadne bolo pre vládnucu autoritu užitočným riešením na istý čas eliminovat' nepohodlných jedincov zo sfér spoločenského a politického vplyvu. ${ }^{10}$ Strata prináležitosti ku kmeňovému spoločenstvu bola pre človeka včasného stredoveku traumatizujúcim aktom, ked’že vyhnanca vylúčením zo spoločenských zväzkov zbavovali dovtedajšieho slobodného postavenia v rámci širšieho kolektívu. ${ }^{11}$ Vyhnaním sa l'udia dostávali mimo práva (ang. outlaw) a z hladiska právnych a politických nárokov sa stávali vydedencami. V stredovekom Anglicku boli l’udia mimo zákona prirovnávaní k vlkom a vyhlásení za štvancov; prostredníctvom vyslovenia legálnej formulky caput gerat lupinum („nech nosí vlčiu hlavu“) boli vydedenci vystavení beztrestnému zabitiu zo strany akéhokol'vek človeka. ${ }^{12}$ Trest pre človeka, ktorý sa

7 Annales regni Francorum. ad. a. 788. In MGH : Scriptores rerum Germanicarum in usum scholarum (d'alej SS rer. Germ.). KURZE, Fridericus (ed.). Hannoverae : Hahniani, 1895, s. 81-82.

8 ,...et pauci Baioarii, qui in adversitate domni regis Caroli perduare voluerant, missi sunt in exilio." Annales regni Francorum. ad. a. 788, s. 82. Preklad podla: STEINHÜBEL, Ján. Nitrianske kniežatstvo: Počiatky stredovekého Slovenska. 2. prepracované vydanie. Bratislava : Rak, 2016, s. 132.

9 Anonymi Vita Hludowici imperatoris 31. In Magnae Moraviae fontes historici II : Textus biographici, hagiographici, liturgici (d’alej MMFH II). BARTOŇKOVÁ, Dagmar - VEČERKA, Radoslav (eds.). Praha : Koniasch Latin Press, 2010, s. 16. K d’alším príkladom vypudenia do exilu v latinských prameňoch z 8 . - 9. storočia pozri: STEINHÜBEL 2016, s. 131-133.

10 Vyhnanie významného mocenského aktéra mohlo byt' v niektorých prípadoch výhodné pre obe strany - královskú autoritu aj vyhnanca. Na príklade vyhnania kastílskeho šlachtica Rodriga Díaza, známeho ako El Cid, králom Alfonsom VI. v poslednej tretine 11. storočia sa dá ilustrovat', že exil mohol v stredovekých podmienkach slúžit' aj na dočasné vyradenie vplyvnej osoby z politického boja. V tomto prípade kastílsky šlachtic neprišiel k zásadnejšej ujme, naopak bolo mu umožnené mocensky sa realizovat' v inom prostredí. Pozri: MCGLYN, Michael. Exile and the Nature of Law in Medieval Castile (The Un-Lawing of the Cid). In Interface. Journal of European Languages and Literature, 2018, roč. 3, č. 5, s. 63-96.

11 STEINHÜBEL, Ján. Kapitoly z najstarších českých dejín. Kraków : Spolok Slovákov v Pol’sku 2012, s. 12-17. 12 Beztrestné zabitie vyhnaných štvancov ako legálny rozsudok zrušil až v 14. storočí anglický král’ Eduard III. PUGH, Ralph. Early Registers of English Outlaws. In The American Journal of Legal History, 1983, roč. 27, č. 4, s. 319. Podla staršieho, ale dnes už neudržatel'ného názoru Felixa Liebermana malo byt' vypudenie (Freidlosigkeit, friðlauss) ako osobitý trestno-právny koncept importované do anglo-saského prostredia zo Škandinávie. LIEBERMANN, Felix. Die Friedlosigkeit bei den Angelsachsen. In Festschrift für Heinrich Brunner zum siebzigsten Geburtstag dargebracht von Schülern und Verehren. Weimar : Hermann Böhlaus Nachfolger, 1910, s. 17-37. V severských ságach pomerne často vystupujú vylúčené osoby a ludia mimo zákona. Táto skutočnost' viedla k dodnes živej diskusii o postavení a osobitostiach stredovekých štvancov 
aktom vyhnania stáva vlkom (wargus sit), je známy aj z franského prostredia. ${ }^{13}$ Vlastnou komunitou zavrhnutí vydedenci sa tak nezriedka uchylovali k životu na okraji, ktorého pravidlá neraz diktoval zboj a plienenie, a v prípade hierarchicky vyššie postavených vyhnancov najmä hladanie mocenského uplatnenia v iných krajinách. V niektorých prípadoch sa ale jedinec vylúčený mimo kolektívu mohol za konkrétne stanovených podmienok vykúpit’ alebo opätovne vrátit’ do svojej komunity. ${ }^{14}$

Na účely d’alšieho výkladu je možné schematicky oddelit’ vynútený exil, čiže vypudenie zo spoločenstva vyššou autoritou, a dobrovol'ný exil, ked' jedinec alebo skupina opustili krajinu či obec z vlastného rozhodnutia, často však práve kvôli reálnemu ohrozeniu alebo politickému tlaku. Skutočnostou zostáva, že vyhnanstvo malo vo včasnom stredoveku i v neskorších dobách rozličné podoby - trestné nariadenia prikazujúce vypudenie z pospolitosti alebo individuálne rozhodnutie utiect' a hl'adat' útočisko v novom prostredí bývali celkovo podmienené rôznymi dôvodmi.

V písomných prameňoch z 9. storočia sa v súvislosti s moravským prostredím vyskytuje hned' niekol'ko zaujímavých aktérov, ktorí boli z rôznych príčin vyhnaní alebo nútení utiect' do krajín ovládaných kniežatami z mojmírovského rodu. Všeobecne sa dá konštatovat', že z obdobia mojmírovskej Moravy (c. 830 - 907) disponujeme pre oblast' stredného Podunajska oproti predchádzajúcim (a čiastočne aj nasledujúcim) obdobiam pomerne početnými svedectvami o vylúčených či prenasledovaných osobách, ktoré boli svojho času skutočnými renegátmi - odpadlíkmi a exulantmi snažiacimi sa znovunadobudnút' vplyvné postavenie alebo iba prežit' politické turbulencie nepokojnej doby. ${ }^{15}$ Napriek skúposti prameňov na bližšie detaily o postavení či konaní vyhnancov je možné z dostupných svedectiev v prevažne východofranských naračných textoch načrtnút’ aspoň rámcový pohlad

\footnotetext{
ako špecifických jedincov severských spoločenstiev. K tomu pozri: POILVEZ, Marion. Outlaws of the Northern Seas: A comparision in the northern corpus. In JENNINGS, Andrew - REEPLOEG, Silke - WATT, Angela (eds.) Northern Atlantic Islands and the Sea : Seascapes and Dreamscapes. Cambridge : Cambridge Scholars Publishing, 2017, s. 97-112; AHOLA, Joonas. Outlawry in the Icelandic Family Sagas [nepublikovaná dizertácia]. Helsinky : University of Helsinky, 2014. K revízii Liebermannovej tézy o výlučne škandinávskom pôvode inštitútu vyhnanstva pozri: VAN HOUTS, Elisabeth. The Vocabulary of Exile and Outlawry in the North Sea Area around the First Millennium. In Exile in the Middle Ages, s. 13-28.

13 Pactus legis Salicae LV, 2. In MGH : Leges I, Leges nationum germanicarum. ECKHARDT, Karl E. (ed.) Hannover : Hahniani, 1962, s. 206.

14 MODZELEWSKI 2017, s. 283.

15 V tejto súvislosti nie je bez zaujímavosti spomenút' Longobardského královského pretendenta Hildigisa z polovice 6. storočia. Ide snád' o prvého z prameňov z včasného stredoveku známeho vyhnanca, ktorý sa zvykne spájat' so stredným Dunajom. Hildigis sa ako legitímny, ale vyhnaný dedič panovníckeho titulu zapojil do mocenských bojov proti Longobardom na strane znepriatelených Gepidov. Jeho renegátske výboje, ktoré podnikal aj z území Slovanov, v hrubých obrysoch zaznamenal: PROCOPIUS. De bello Gothico III 34, 35. In Procopii Caesariensis opera omnia, Vol. I : De bellis libri I. - IV. HAURY, Jacob - WIRTH, Gerhard (eds.). Lipsiae : B. G. Teubner, 1962. Porovnaj: PAULUS DIACONUS. Historia Langobardorum I 21. In MGH : Scriptores rerum Langobardicarum et Italicarum saec. VI. - IX. WAITZ, Georg (ed.). Hannoverae : Imp. Bibliopolii Hahniani, 1878. Treba ale dodat', že pokým tradičný výklad slovenskej a českej historiografie používa Hildigisov príbeh zaznamenaný Prokopiom na dokazovanie prítomnosti Slovanov na strednom Dunaji v 6. storočí (TŘEŠTíK, Dušan. Počátky Přemyslovců. Praha : Nakladatelství Lidové noviny, 1997, s. 39-44, 46-49; STEINHÜBEL 2016, s. 37-38), tak byzantský autor pravdepodobne popisuje Hildigisove pôsobenie u Slovanov na dolnom Dunaji. K tomu pozri: CURTA Florin. Utváření Slovanů (se zvláštním zřetelem k Čechám a Moravě). In Archeologické rozhledy, 2008, roč. 60, č. 4, s. 661-663; CURTA, Florin. The early Slavs in Bohemia and Moravia: a response to my critics. In Archeologické rozhledy, 2009, roč. 61, č. 4, s. 734-735; DULINICZ, Marek. The Lombard Headman Called Ildigis and the Slavs. In Archaeologia Adriatica, 2009, roč. 3, č. 1, s. 237-246.
} 
na osoby podielajúce sa na mocenských zápasoch v moravsko-bavorskom pohraničí slovanského a karolínskeho sveta. Niektoré výpovede inak mlčanlivých včasnostredovekých prameňov navyše umožňujú formulovat' opatrné závery o politickom charaktere územia moravských kniežat a jeho vzt’ahu ku východofranskému prostrediu.

\section{Exulant Pribina}

Kým takmer všetky dostupné svedectvá popisujú mužov z bavorsko-franského prostredia, ktorí počas 9. storočia našli azyl na Morave, tak neskorší panónsky knieža slovanského pôvodu Pribina bol, naopak, z oblasti nachádzajúcej sa severne od stredného Dunaja vyhnaný. Pribinove vyhnanie zaznamenal iba spis Conversio Bagoariorum et Carantanorum z roku 870, pochádzajúci zo skriptória salzburského arcibiskupstva. Prameň vznikol so zámerom preukázat' oprávnenost' nároku bavorskej cirkevnej metropoly na Panóniu, kde vtedy pôsobil Metod ako pápežom designovaný arcibiskup. ${ }^{16}$ Text zapísaný anonymným salzburským klerikom hovorí, že v čase, ked' sa Ratbod stal prefektom Východnej marky, čiže niekedy okolo roku 833, prišiel k nemu cez Dunaj „akýsi Pribina vyhnaný Mojmírom, kniežat'om Moravanov".17

Je pozoruhodné, že Conversio na rozdiel od moravského kniežat’a Mojmíra (dux Maravorum) neuvádza, aké mal Pribina postavenie; v texte je uvedený iba neurčito ako quidam. Formulácia prameňa naznačuje, že v očiach autora bol Mojmír na hierarchicky vyššej pozícii. ${ }^{18}$ Hodnost' kmeňového kniežat’a s centrom v Nitre Pribinovi prisúdila až historiografia, a to na základe vety v nasledujúcej kapitole, kde sa uvádza svätenie kostola na Pribinovom naddunajskom majetku (proprietas), ktorý mal vlastnit’ ešte pred osudným vyhnaním. ${ }^{19}$ Moderné historické bádanie z údaja o „mieste nazývanom Nitrava“ a z niekol'kých d’alších nepriamych indícií vyvodzuje, že Pribina bol pôvodne nitrianskym kniežat’om, ktorý vládol ako dux gentis svojmu kmeňovému kniežatstvu rozprestierajúcemu sa na území dnešného Slovenska. ${ }^{20}$ Conversio ako jediný text popisujúci Pribinove vyhnanie však umožňuje aj odlišný výklad.

Pribinova pôvodná naddunajská dŕžava je zahalená tmou, ktorú nijaký súdobý prameň neosvetl'uje. ${ }^{21}$ Conversio ako písomný doklad o nárokoch salzburskej die-

16 K motivácii vzniku prameňa a jeho autorstvu pozri: NÓTÁRI, Tamás. Conversio Bagoariorum et Carantanorum - Document of an early medieval show trial. In Sectio Juridica et Politica 2007, roč. 25, č. 1, s. 95-114; Conversio Bagoariorum et Carantanorum. Das Weißbuch der Salzburger Kirche über die erfolgreiche Mission in Karantanien und Pannonien. WOLFRAM, Herwig (ed.). Ljubljana ; Laibach : Slovenska akademija znanosti in umetnosti, 2012, s. 16-33.

17 Die Conversio Bagoariorum et Carantanorum und der Brief des Erzbischofs Theotmar von Salzburg (d'alej Conversio). LOŠEK, Fritz (ed.). Hannover : Hahnsche Buchhandlung, 1997, s. 120: „In cuius spacio temporis quidam Priwina exulatus a Moimaro duce Maravorum supra Danubium venit ad Ratbodum."

18 K tomu pozri: SIEKLICKI, Jan. Quidam Priwina. In Slavia Occidentalis, 1962, roč. 22, s. 115-146. Obaja aktéri sa v predmetnej vete v Conversio spomínajú prvýkrát.

19 Conversio, Cap, 11, s. 122: „Cui quondam Adalrammus archiepiscopus ultra Danubium in sua proprietate loco vocato Nitrava consecravit ecclesiam."

20 Podrobne aj s d’alšou literatúrou pozri: STEINHÜBEL 2016, s. 111-137.

21 Nitrianske kniežatstvo predstavuje skôr hypoteticky predpokladaný, než v prameňoch bezpečne zachytený mocenský útvar. Porovnaj: STEINHÜBEL 2016, s. 111-115; TŘEŠTÍK, Dušan. Vznik Velké Moravy. Praha : Nakladatelství Lidové noviny, 2001, s. 127-135. Najstarší doložený názov Nitry sa hodnoverne (!) uvádza až 
cézy na Panóniu relatívne obšírne popisuje jeho pôsobenie až po vyhnaní. Vzhl'adom na intenciu textu kladie do popredia salzburské záujmy a kontakty biskupov a misionárov s Pribinovým neskorším územím s centrom v Blatnohrade / Mosapurcu. ${ }^{22}$ Avšak oblast', z ktorej bol Pribina vyhnaný moravským Mojmírom, ostáva mimo záujmu autora Conversio. Tento prameň o pôvodnej dŕžave referuje iba nepriamo, v dvoch vyššie citovaných vetách z kapitoly 10. a 11. Väčšinovo prijímaný výklad, predpokladajúci že Pribina sídlil v Nitre, sa zakladá práve na druhej vete hovoriacej o svätení kostola salzburským arcibiskupom Adalramom. Stredoeurópska medievistika však zvyčajne neberie do úvahy spornú hodnovernost' vety z 11 . kapitoly. ${ }^{23}$ Prinajmenšom od 30 . rokov 20. storočia bolo bádatelom zrejmé, že veta o svätení kostola v Nitre nezapadá do kontextu danej pasáže a jednoznačne ide o vsuvku. ${ }^{24}$ Otázkou stále zostáva či ide o vsuvku z druhej polovice 9. storočia, ktorá bola do textu iba štylisticky nešikovne včlenená pôvodným autorom, ${ }^{25}$ originálnu marginálnu glosu prevzatú do hlavného textu neskorším odpisovatel'om ${ }^{26}$ alebo až o neskoršiu interpoláciu. ${ }^{27}$

Vzhl'adom na skutočnost', že vetu nemáme doloženú v najstaršej dochovanej rukopisnej vetve, ${ }^{28}$ ako aj kvôli faktickej nepravdepodobnosti svätenia kostola v relatívne periférnej Nitre v prvej tretine 9. storočia, sa spomenutá zmienka zdá byt' skôr neskorším prípiskom. Z údaja o svätení krestáanského chrámu v gescii Salzburgu navyše nie je celkom jasné, akým veriacim mal v danej dobe slúžit', ked'že samotný Pribina bol podla toho istého prameňa pokrstený až po vyhnaní. ${ }^{29}$ Tento rozpor v texte Conversio sa väčšinou vysvetluje hypotézou o bavorskej manželke

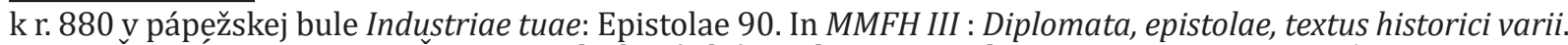
BARTOŇKOVÁ, Dagmar - VEČERKA, Radoslav (eds.). Praha : Koniasch Latin Press, 2011, s. 165-166.

22 K Pribinovmu pôsobeniu a postaveniu v Pannónii, a k tendenčnému zámeru Conversio pozri: WOLFRAM, 2012, s. 28-33, 183-192; ŠTIH, Peter. Priwina: slawischer Fürst oder fränkischer Gräf? In BRUNNER, Karl MERTA, Brigitte (eds.) Ethnogenese und Überlieferung. Angewamdte Methoden der Frühmittelalterforschung. Wien : R. Oldenbourg Verlag, 1994, s. 209-222.

23 Hodnovernost' zmienky spochybnili najmä Martin Eggers a Charles Bowlus, ktorí však jej interpretáciu podriad'ujú svojmu dlhodobému (a diskutabilnému) zámeru, pokúšajúcemu sa lokalizovat' jadro mojmírovskej Moravy na územiach súčasného Srbska, Bosny či Mad’arska. BOWLUS, Charles R. Franks, Moravians, and Magyars : The Struggle for the Middle Danube 788 - 907. Philadelphia : University of Pennsylania Press, 1995, s. 105; EGGERS, Martin. Das Größmährische Reich. Realität oder Fiktion? Stuttgart : Anton Hiersemann, 1999, s. 159-160. Zmienku o Pribinovom kostole kritickejšie posudzuje vzhl'adom na archeologické situácie v Nitre aj mad’arský archeológ Béla Szőke. Najnovšie: SZŐKE, Béla M. Priwina in Nitra und Mosaburg. In FUSEK, Gabriel (ed.) Archäologische Studien zum frühen Mittelalter. Nitra : Archeologický ústav, 2017, s. $176-177$. Historickú spol'ahlivost' tejto vety čiastočne spochybňuje aj Vladimír Vavř́nek v svojej novšej populárne ladenej knihe: VAVŘíNEK, Vladimír. Cyril a Metoděj mezi Konstantínopolí a Římem. Praha : Vyšehrad, 2013, s. 101-103.

24 WEINGART, Miloš. Pribina, Kocel' a Nitra v zrkadle prameňov doby cyrilometodejskej. In STANISLAV, Ján (ed.) Ríša Vel'komoravská. Praha : L. Mazáč, 1933, s. 334-335; KOS, Milko. Conversio Bagoariorum et Carantanorum. Razprave Znanstvenega Družstva : Ljublana, 1936, s. 74.

250 tejto možnosti uvažoval najprv: TŘEŠTíK 2001, s. 113-114. Rovnako aj: LYSÝ, Miroslav. Moravania, Mojmírovci a Franská ríša: Štúdie $k$ etnogenéze, politickým inštitúciám a ústavnému zriadeniu na území Slovenska vo včasnom stredoveku. Bratislava : Atticum, 2014, s. 91.

26 KOS 1936, s. 74; LOŠEK 1997, s. 123 pozn. č. 130.

27 Herwig Wolfram v najnovšom kritickom vydaní prameňa hodnotí túto vetu ako interpoláciu: WOLFRAM 2012, s. 51 . O neskoršom pôvode zmienky uvažuje aj BOWLUS, Charles. Nitra: when did it become a part of the Moravian realm? Evidence in the Frankish sources. In Early Medieval Europe, 2009, roč. 17, č. 3, s. 319, 327.

28 Iba tri rukopisy Conversio $\left(\mathrm{W}_{3}, \mathrm{~W}_{4}\right.$ a $\left.\mathrm{W}_{6}\right)$ obsahujú predmetnú vetu. Porovnaj rukopisné stemma vypracované Fritzom Lošekom: LOŠEK 1997, s. 16.

29 Conversio, Cap. 10, s. 120: „Qui statim illum praesentavit domno regi nostro Hludowico, et suo iussu fide instructus baptizatus est in ecclesia sancti Martini loco Treisma nuncupato..." 
Pribinu (snád’ z vilhelmovského rodu), ktorá mala údajne príst’ do Nitry sprevádzaná svojimi krestanskými vernými. Novovybudovaný kostol v Nitre mal podla úvah historikov slúžit' práve Pribinovej manželke a jej sprievodu, ako aj d’alším krestanským cudzincom. ${ }^{30}$ Celkovo bolo dodnes vyslovených niekol'ko zaujímavých hypotéz, snažiacich sa ozrejmit', prečo Adalram ako hlava bavorskej arcidiecézy podnikol cestu do vzdialenej a pohanskej Nitry, aby tam vysvätil kostol na majetku človeka, ktorý ani nebol krestanom (pričom Pribinu nepokrstil ani pri príležitosti údajnej vysviacky) a ktorého doménu beztak nijaký súdobý prameň nespomína. ${ }^{31}$ V̌̌etky predpoklady väčšinou vychádzali len z apriórneho presvedčenia o mocenskom význame Nitrianskeho kniežatstva, ako aj z názoru, že Salzburg si od konca 8. storočia nárokoval územie severne od stredného Dunaja čiže aj „Nitriansko“, ktoré malo byt' zhruba do r. 833 samostatným kniežatstvom. V literatúre sa bežne uvažuje, že v povodí Váhu a Nitry christianizačne pôsobila salzburská misia, kým na Morave misionári z Pasova. ${ }^{32}$ Faktom zostáva, že nárok na naddunajské územia je písomne doložený iba u predstavitelov Pasovskej diecézy, kým misijné záujmy Salzburgu podla Conversio, aj podla iných prameňov ${ }^{33}$ v prvej polovici 9. storočia nesiahali za dunajské brehy. Pravdepodobne interpolovaná veta z 11. kapitoly Conversio je jedinou zmienkou, ktorá kladie salzburské pôsobenie $\mathrm{v}$ naddunajskom priestore do prvej polovice 9. storočia, respektíve pred rok $829 .{ }^{34}$

Je však celkom pravdepodobné, že veta o Nitrave mohla byt' do textu vpísaná niekedy medzi 10. - 12. storočím. Až v neskoršom období je možné oprávnenejšie predpokladat' záujem salzburských arcibiskupov o dokazovanie ich zásluh pri christianizácii území na l'avom brehu Dunaja. Z hladiska cirkevnej správy bola Nitra pevnejšie etablovaná až od roku 880, ked' krátkodobo získala status biskupstva. ${ }^{35}$ Domnelý skutok pokrest’ančovat’ dovtedy ešte pohanské územie Nitrianska postavením kostola mohol neskorší odpisovatel’ pomocou interpolácie v 11. kapitole Conversio zámerne pripísat’ Adalramovi, a to bez ohl'adu na reálnu situáciu

30 WOLFRAM, Herwig. Salzburg, Bayern, Österreich. Die Conversio Bagoariorum et Carantanorum und die Quellen ihrer Zeit. Wien, München : R. Oldenbourg Verlag, 1995, s. 311-312; STEINHÜBEL 2016, s. $127-128$.

31 Súhrnný prehlad názorov na výstavbu kostola v Nitre s dôrazom na slovenskú a českú historiografiu pozri: IVANIČ, Peter. Pribinov kostol v Nitre v zrkadle historiografie. In Konštantínove listy, 2008, roč. 1, č. 1, s. 60-69. Pre stručnejší prehlad d'alších názorov pozri: TŘEŠTIK 2001, s. 121-122.

32 Porovnaj: MARISNA, Richard. Začiatky cirkevnej organizácie na Slovensku (Od prelomu 8./9. až do začiatku 11. storočia). In Slovenská archivistika, 1995, roč. 30, č. 2, s. 115-116; STEINHÜBEL 2016, s. $124-125$. 33 Jediným pramenným svedectvom, ktoré spája pôsobenie, a teda aj misijné záujmy Salzburgu s územím naddunajského Nitrianska v prvej polovici 9. storočia je vsuvka z 11. kapitoly Conversio o Adalramovom svätení kostola. Avšak ani samotné Conversio, Cap. 8, s. 116, ani Paulínove Dictatus patriarchae zo synody na brehoch Dunaja (K tomu pozri: KOŽIAK, Rastislav. Christianizácia Avarov a Slovanov na strednom Dunaji: Príbeh svätcov-misionárov, svätá vojna alebo kultúrny šok? In KOŽIAK, Rastislav - NEMEŠ, Jaroslav (eds.) Svätec a jeho funkcie v spoločnosti I. Bratislava : Chronos, 2006, s. 133.) a ani neskoršie falzum hlásiace sa do roku 829 (Spuria 107. In MMFH III, s. 93-94.) neimplikuje nárok Salzburgu na územia severne za hranicou na Rábe a Dunaji. Bližšie pozri: HARVÁT, Matej. Mocenské postavenie Pribinovej naddunajskej dŕžavy. In Konštantínove listy (v tlači).

34 K pôsobeniu Salzburgu na územiach severne od Dunaja pred rokom 829 porovnaj: LYSÝ 2014, s. 90-91.

35 Epistolae 90. In MMFH III, s. 205. Podl'a Theotmarovho listu (Epistolae 109. In MMFH III, s. 198-199), ktorého obsah napriek tendenčnosti netreba v tejto súvislosti spochybňovat', ešte ani v roku 900 nebol celkom zretel'ný nárok na Nitriansko zo strany východofranských misijných centier. Z dikcie oficiálneho listu bavorského episkopátu totiž vyplýva, že novozriadená nitrianska diecéza nebola (na rozdiel od Moravy) ešte objektom cirkevno-administratívnych záujmov Pasova, tým menej pravdepodobne samotnej salzburskej arcidiecézy. K tomu: TŘEŠTÍK 2001, s. 116. 
v prvej polovici 9. storočia. Z písomných a archeologických prameňov totiž nie sú v rámci Nitrianska v období, ku ktorému sa vzt’ahuje predmetná veta, dostatočne doložené prejavy christianizačnej činnosti. ${ }^{36}$ Správu o existencii kostola postavenom v Nitre a vysvätenom samotným prímasom bavorskej cirkevnej provincie treba posudzovat' kriticky aj z toho dôvodu, že do dnešných dní neboli v okolí Nitry archeologickým výskumom presvedčivo lokalizované pozostatky sakrálnej architektúry ani identifikované prejavy christianizácie, ktoré by sa dali datovat' do prvej polovice 9. storočia. ${ }^{37}$ Bez spoliehania sa na často nepreukázatel'né historiografické konštrukcie a pri neprijatí hodnovernosti vety o Adalramovom svätení kostola, pramene v skutočnosti nepotvrdzujú spojitost' Pribinu s Nitrou. Odkial' bol teda tento významný človek so svojou družinou (cum suis), ako aj so synom Kocel’om a snád' aj s predpokladanou bavorskou manželkou vyhnaný Mojmírom?

Nitra sa javí byt' ako prirodzená odpoved'. Územie medzi Váhom a Hronom nepochybne disponovalo významným postavením v rámci moravského kniežatstva. Ustanovenie nitrianskeho biskupstva v roku $880^{38}$, bez ohl'adu na reálnu podobu akú nová diecéza nadobudla, dokladá význam Nitrianska v mocenskej organizácii Svätoplukovho panstva. Pribinova „Nitrava“ však kvôli absencii presvedčivých archeologických dôkazov, ktoré by svedčili o výraznejších mocenských elitách na územiach medzi Váhom a Hronom v prvej polovici 9. storočia, ${ }^{39}$ ako aj kvôli neudržatel'nosti chronológie tzv. blatnicko-mikulčického horizontu ${ }^{40}$ a nedostatku písomných dokladov o sformovaní osobitného kniežatstva či politického spoločenstva (gens) „Nitranov“ stále vzbudzuje viac otázok a pochybností než jasných záverov. Napriek tradičnému a zvyčajne neproblematizovanému výkladu o vzniku Vel'kej Moravy spojením Moravy a Nitry je v skutočnosti otázne, kedy sa Nitriansko mohlo stat' súčastou moravskej domény a či je vôbec oprávnené bezvýhradne

36 Porovnaj súbor archeologických nálezov z územia dnešného Slovenska, ktoré niektorí archeológovia datujú do 9. - 10. storočia: HANULIAK, Milan - PIETA, Karol. Odraz christianizácie v hnutelných prameňoch z 9. storočia vo východných častiach Vel'kej Moravy. In KOUŘIL, Pavel (ed.) Cyrilometodějská misie a Evropa. 1150 let od př́chodu soluňských bratří na Velkou Moravu. Brno : Archeologicky ustav Akademie věd Česke republiky, 2014, s. 136-149. Datovanie značnej časti predmetov krest'anského charakteru (napr. pektorálne kríže z rôznych sídlisk, či fragmenty oltára a d’alších predmetov z lokality Bojná) do prvej polovice 9. storočia je sporné, resp. sú tieto predmety datované až do mladšieho obdobia. Z území Nitrianska je pre archeologické lokality datované do prvých dvoch tretín 9. storočia charakteristická predovšetkým absencia sakrálnej architektúry a výraznejších prejavov krest’anského pohrebného rítu. Porovnaj najnovšie: BEDNÁR, Peter - RUTTKAY, Matej. Nitra and the Principality of Nitra after the Fall of Great Moravia. In KOUŘIL, Pavel - PROCHÁZKA, Radoslav (eds.) Moravian and Silesian Strongholds of the Tenth and Eleventh Centuries in the Context of Central Europe. Brno : The Czech Academy of Sciences, Institute of Archaeology, 2018, s. $234-235$.

37 Napriek tomu archeologické bádanie najmä na základe sekundárnych fragmentov počíta opatrne s existenciou Pribinovho kostola v Nitre. Pozri: FUSEK, Gabriel - BEDNÁR, Peter. Die (vermutete) Kirche am Burgberg von Nitra (Slowakei). In PIPPAL, Martina - DAIM, Falko (eds.) Frühmittelalterliche Wandmalereinen aus Mähren und der Slowakei. Archäologischer Kontext und herstellungstechnische Analyse. Innsbruck : Universitätsverlag Wagner, 2008, s. 31-45; BEDNÁR - RUTTKAY 2018, s. 233-234.

38 Epistolae 90. In MMFH III, s. 169-170: „Ipsum quoque presbiterum nomine Uuichinus, quem nobis direxisti, electum episcopum consecravimus sacntae ecclesiae Nitrensis..."

39 HARVÁT, Mocenské postavenie (v tlači).

40 K tomu súhrnne: ROBAK, Zbigniew. The Origins and the Colapse of the Blatnica-Mikulčice Paradigm. In Slovenská archeológia, 2017, roč. 64, č. 1, s. 99-153; UNGERMAN, Simom. Tzv. blatnicko-mikulčický horizont a jeho vliv na chronologii raného středověku. In Archeológia supplementum 4 : Zborník SNM, Bratislava : Slovenské národné múzeum, 2011, s. 135-151. Hana Chorvátová upozorňuje na dôsledky spochybnenia koncepcie blatnicko-mikulčického horizontu, ktoré môžu ovplyvnit' historické interpretácie Nitrianskeho kniežatstva v prvej pol. 9. storočia: CHORVÁTOVÁ, Hana. Následný alebo paralelný vývoj avarských a tzv. vel'komoravských pohrebísk. In CSÜTÖRTÖKY, József (ed.) Iuxta Danubium, Spravodaj podunajského múzea v Komárne 16 Komárno : Podunajské múzeum, 2018, s. 144-150. 
prijat' výklad o Mojmírovej expanzii na juhozápadne Slovensko. Územie medzi Váhom, Dunajom a Hronom patrilo v 9. storočí k oblastiam, ktoré mocensky kontrolovali moravské kniežatá, avšak domnievam sa, že nie je nevyhnutné spájat' ovládnutie Nitrianska (už) s Mojmírom I. V súčasnosti totiž de facto neexistuje jediná hodnoverná pramenná zmienka, ktorá by potvrdzovala notorickú tézu, že Mojmír dobyl Nitru a Pribinu odtial' následne vyhnal. ${ }^{41}$ Otázku územnej príslušnosti Nitrianska na tomto mieste nemožno bližšie rekonštruovat', je ale potrebné vrátit’ sa k jedinej hodnovernej vete v Conversio vzt’ahujúcej sa k Pribinovej naddunajskej dŕžave.

Zmienka o vyhnaní moravským kniežatom nehovorí nič o Pribinovom nezávislom kniežatstve, naopak, svojou formuláciou skôr naznačuje, že okolo roku 833 Mojmír nevyháňal samostatného kmeňového vládcu, ale zrejme významného vel’moža či „druhostupňové knieža“," ktorý bol voči moravskému panovníkovi do istej miery mocensky závislý. ${ }^{43}$ Nasvedčuje tomu nielen absencia kniežacej hodnosti Pribinu, ktorý je v Conversio - napriek významu, ktorý mu celkovo tento prameň pripisuje - uvedený iba ako „akýsi“ (quidam), ale najmä samotná forma latinského slova exulatus. V Conversio sa tak nedočítame o Mojmírovom útoku a dobývaní Nitry, ale iba o skutočnosti, že Pribina bol vyhnaný moravským kniežatom, prípadne „od Mojmíra“ (quidam Priwina exulatus a Moimaro). Jan Siekłicky si už dávnejšie všimol, že v Pribinovom prípade prameň zachycuje bežný príklad vypovedania podriadeného človeka do exilu. Pol'ský bádatel' v dvoch štúdiách upozornil na skutočnost', že Conversio napriek terminologickej rozkolísanosti včasnostredovekých latinských textov zachováva jednotnú dikciu a celkom určite termín exulatus vypovedá o vypudení nižšie postaveného vel'moža. ${ }^{44} \mathrm{~V}$ prípade Pribinovho

41 Dušan Třeštík, Miroslav Lysý a d’alší však odkazujú na pasáž z Theotmarovho listu z roku 900. Prameň hovorí o bližšie nešpecifikovanom kmeni (gens), ktorý si Svätopluk vojensky podmanil a nechal pokrest'ančit'. Na území tohto kmeňa mal Svätopluk ustanovit’ biskupstvo na čele s Vichingom. Autori zastávajú názor, že v skutočnosti išlo o pisatelov omyl, teda kontamináciu Svätopluka s Mojmírom I. TŘEŠTíK 2001, s. 115116, 277-278; LYSÝ 2014, s. 96-101. Pri tomto presvedčení sa však opät’ vychádza z apriórneho názoru, že Nitru si podrobil práve a jedine Mojmír. Hodnovernost' svedectva o Svätoplukovom podmanení si Nitry, ktorého ozveny možno nájst' aj v mladších kronikách, bádatelia, podla môjho názoru, neopodstatnene diskvalifikujú. Okrem toho, staršie bádanie sa tiež opieralo o pôvodné, avšak dnes už revidované datovanie zánikového horizontu drevozemných hradov na území Slovenska, ktoré stotožnilo ich zánik práve s obdobím vlády Mojmíra. Podla dendrodát boli opevnenia hradov na území Nitrianska zničené v dôsledku požiaru, respektíve vojenského konfliktu až v samom závere 9. storočia alebo začiatkom 10. storočia. Pozri: HENNING, Joachim - RUTTKAY, Matej. Frühmittelalterliche Burgwälle an der mittleren Donau im ostmitteleuropäischen Kontext: Ein deutsch-slowakisches Forschungprojekt. In MACHÁČEK, Jiří - UNGERMAN, Štefan (eds.) Frühgeschichtliche Zentralorte in Mitteleuropa. Břeclav : Verlag Dr. Rudolf Habelt, 2011, s. 259-288; HENNING, Joachim - HEUSSNER, Karl-Uwe et. al. Bojná and the dating of hillforts of the Nitra Principality. contribution of natural sciences to the archaeological research. In PIETA, Karol - ROBAK, Zbigniew (eds.) Bojná 2, Nové výsledky výskumov včasnostredovekých hradísk. Nitra : Archeologický ústav, Slovenskej akadémie vied, 2015, s. 335-345.

42 Porovnaj: LYSÝ, Miroslav. Druhostupňové kniežatá na Morave v 9. storočí. In HURBANIČ, Martin et al. (eds.) Byzantinoslovaca $V$ : Zborník $k$ životnému jubileu Tatiany Štefanovičej. Bratislava : Byzantologický seminár Alexandra Avenaria pri Katedre všeobecných dejín FiF UK, 2014, s. 123-127.

43 Názor o podriadenom postavení Pribinu voči Mojmírovi zastávalo už niekol’ko zahraničných bádatelov, výberovo najmä: DIETTRICH, Zdenko R. Christianity in Great-Moravia. Gronigen : Instituut voor middeleeuwsche geschiedenis, 1962, s. 67-72; VLASTO, Alexis P. The Entry of the Slavs into Christendom. Cambridge : Cambridge University Press, 1970, s. 24. SIEKLICKI 1962, s. 115-146; TŘEŠTÍK 2001 , s. 110. Samostatné a nezávislé Pribinovo kniežatstvo z textu Conversio ešte neodvodzovali ani obrodeneckí historici 19. storočia ako Pavol Jozef Šafárik, Jonáš Záborský či František Vít’azoslav Sasinek. K tomu pozri: STEINHÜBEL 2016, s. 126 pozn. 431.

44 SIEKLICKI 1962, s. 159-164; SIEKLICKI, Jan. „Priwina exulatus“. In Pamietjmol Słowiański, 1967, roč. 17, s. 161-165. 
poslania do exilu máme množstvo analógií z franských prameňov, ktoré používajú obdobnú formu označenia vyhnanstva ako Conversio. ${ }^{45}$ Použitý termín exulatus teda nenaznačuje, že by išlo o vyhnanie alebo útek, ktorý mal byt' vynútený v dôsledku moravského útoku na samostatné kniežatstvo.

V tejto súvislosti je vel'mi dôležité, že autor Conversio pri popise vojenskej porážky a následnom vyhnaní Gótov, Gepidov, Rimanov či Avarov vždy použil iba sloveso expello, resp. expulso. ${ }^{46}$ Latinské pramene franskej proveniencie neoznačovali vyhnanie podrobených protivníkov termínom pre exil (subst. exilio, verb. exulo), tak ako je to uvedené v Conversio v prípade vyhnania Pribinu.

Z obdobia 8. - 10. storočia poznáme asi iba jediný prípad, ked' pisatel' nepoužil pre vypudenie podrobených l'udí adekvátny termín (expello), ale z hl'adiska literárnej praxe nesprávnu formuláciu, označujúcu vyhnanie do exilu. Ján Steinhübel upozornil, že v Theotmarovom liste ${ }^{47}$ je pre vyhnanie podmanených obyvatelov Panónie použitá formulácia pre exil (exilio deputaverunt), na rozdiel od zvyčajného označenia násilného vypudenia (expellere). Táto skutočnost’ by vice versa mohla naznačovat', že aj správa o Pribinovom vyhnaní vlastne vypovedá o vojenskom podmanení. ${ }^{48}$ Theotmarov list z roku 900 je však ojedinelým príkladom použitia termínu exilio v zmysle vyháňania podmaneného obyvatel'stva dobyvatel'mi. Dobový terminologický úzus vychádzal z jasného odlišovania medzi vypovedaním do exilu (exilio est deportatus) a vyhnaním od nepriatel'a v dôsledku útoku (expulsus est). ${ }^{49}$ Predstava, že útočiace mad’arské vojská vykázali zajatých Panóncov do exilu, je zjavne formálnou dezinterpretáciou Theotmarovho listu, ked’že v texte sa opisuje vyhnanie podmanených l'udí. Priwina exulatus však v dikcii Conversio ničím nedáva tušit' vypudenie porazeného nepriatel'a. Z formulácie, naopak, vyplýva, že Pribina bol kvôli bližšie neznámemu dôvodu vykázaný do exilu Mojmírom ako vyššou autoritou, pričom sa dá oprávnene usudzovat', že musel so svojou družinou odíst' z nejakého naddunajského územia (supra Danubium venit), ktoré už v prvej tretine 9. storočia ovládal ako jednu zo súčasti širšej moravskej oblasti. Ak neprijmeme hodnovernost' vsuvky z 11. kapitoly, ${ }^{50}$ potom nie je vylúčené, že Pribinova pôvodná dŕžava nemusela byt' nutne Nitra, ale eventuálne aj oblast' Devínskej brány na sútoku Moravy a Dunaja. ${ }^{51}$

45 Mnohé príklady uvádza: STEINHÜBEL 2016, s. 131-136.

46 Conversio, Cap 6, s. 110: „...et amplius Huni ex sedibus suis in aquilonari parte Danubii in desertis locis habitantes, transfretantes Danubium expulerunt Romanos et Gothos atque Gepidos...Tunc vero Sclavi post Hunos inde expulsos venientes coeperunt istis partibus Danubii diversas regiones habitare. Sed nunc, qualiter Huni inde expulsi sunt et Sclavi inhabitare coeperunt...“; Conversio, Cap. 10, s. 120: „...coeperunt populi sive Sclavi vel Bagoarii inhabitare terram, unde illi expulsi sunt Huni, et multiplicari."

47 Kritické vydanie s komentárom pozri: LOŠEK 1997, s. 55-87, 138-157.

48 Ján Steinhübel predpokladá, že Pribina bol Mojmírom najprv vojensky porazený, potom zajatý a následne vyhnaný. STEINHÜBEL 2016, s. 134-137.

49 SIEKLICKI 1967, s. 164.

50 Podobne argumentuje Charles Bowlus, avšak snažiac sa predovšetkým potvrdit’ jednu z „alternatívnych“ lokalizácií mojmírovského kniežatstva v južnej Panónii. Pozri: BOWLUS 2009, s. 319, 327.

51 Fuldské anály spomínajú osobité regnum ovládané Svätoplukom v rámci moravského kniežatstva. Annales Fuldenses ad a. 869, a. 870 (d’alej Ann. Fuld.). In MGH : SS rer. Germ. KURZE Friedericus (ed.). Hannoverae : Hahniani, 1891, s. 69, 70. Toto Svätoplukovo panstvo sa spája s Nitrou iba na základe nepriamych indícii, ako aj akceptovaním hodnovernosti vety z 11. kapitoly v Conversio. Najnovšie originálnu argumentáciu v tomto smere predložil: LYSÝ 2014, s. 101-107. Avšak o možnom situovaní regnum Zuentibaldi do oblasti Devínskej brány s centrom na Bratislavskom hrade uvažoval už Dušan Třeštík. Pozri TŘEŠTíK 2001, s. 195. 
Pribinov prípad je v porovnaní s ostatnými vyhnancami a utečencami spomínanými vo franských prameňoch unikátny práve v tom, že ide o ojedinelý doklad uplatňovania panovníckeho práva vypovedania do exilu v moravskom prostredí v 9. storočí, ktorého aplikácie sú inak známe len z odlišných regiónov a iných právnych systémov. Conversio pomerne podrobne uvádza oblasti, kam sa Pribina so svojou družinou a synom Kocelom (o predpokladanej bavorskej manželke sa prameň nezmieňuje) uchýlili so žiadost’ou o azyl. Vd'aka salzburskému spisu sme informovaní, že Pribina ako exulant najprv smeroval k východofranskému markgrófovi Ratpodovi. Následne bol na príkaz Ludovíta II. Nemca pokrstený v Kostole svätého Martina v Traismaueri (Treisma), čo mu nepochybne otvorilo mnohé, pohanovi dovtedy zatvorené dvere pre politické manévrovanie. ${ }^{52}$ Po nezhodách s Bavormi, odchode k Bulharom, neskoršom úteku k slavónskemu kniežat'u Ratimírovi a konečne, po odchode ku grófovi Salachovi, ktorý ho definitívne uzmieril s Ratpodom, sa uzatvára exulantská dráha Pribinu. Prostredníctvom jedného z najskoršie dosvedčených majetkových benefícií v strednej Európe nadobudol tento vysoko postavený slovanský vyhnanec okolo roku 840 správu nad oblast'ou v dolnej Panónii. ${ }^{53}$ Treba ale dodat', že v priamej závislosti na franskej moci. ${ }^{54}$

\section{Exules v moravskom kniežatstve}

Ked'že najväčší počet zachovaných prameňov vztahujúcich sa k moravskému kniežatstvu pochádza z latinského kultúrneho okruhu, je celkom prirodzené, že dostupné správy hovoria predovšetkým o vyhnancoch a utečencoch z franského prostredia. V písomnostiach evidujeme najmä osoby exulantov (exules) z karolínskeho západu, čo je vo všeobecnosti symptomatické pre mocenskú pozíciu mojmírovskej domény. Na územiach moravských Slovanov hladali útočisko a spojenectvá mnohí významní predáci, ktorí sa snažili dostat' čo najd’alej od dosahu právomoci východofranského královského dvora, pričom v novom prostredí mohli nachádzat' vhodné podmienky pre d’alšie pôsobenie. Mojmírovská Morava sa stávala z hladiska bavorských politických elít, napriek určitej periférnej pozícii, čoraz zretel'nejšie súčast’ou krest'anského sveta. Zdá sa byt' reálne, že kniežatstvo Mojmírovcov franská moc chápala ako odlišnú právnu oblast'. Napriek do istej miery závislému postaveniu moravského kniežat'a voči východofranskému panovníkovi, ${ }^{55}$ L'udovít II. (843 - 876), Karloman (876 - 880), Karol III. (882 887), Arnulf (887 - 899) a zjavne ani L'udovít IV. (900 - 911) počas druhej polovice 9. storočia nepovažovali Moravu za územie kam mala siahat' pôsobnost' ich právneho poriadku. V prameňoch z franského okruhu síce pozorujeme existenciu určitých hierarchických nárokov ríšskeho dvora, ako aj bavorských cirkevných in-

52 Conversio, Cap. 10, s. 120-122.

53 Conversio, Cap. 10, s. 122.

54 ŠTIH 1994, s. 220-225; SZŐKE 2017, s. 181-187.

55 K otázke a limitom franskej zvrchovanosti a politických záväzkov moravských panovníkov voči východofranským králom pozri podrobne: LYSÝ, Miroslav. Mojmírovská Morava na hraniciach s impériom. In Forum Historiae, 2014, roč. 8, č. 2, s. 98-129; LYSÝ 2014, s. 149-224. Porovnaj: HAVLÍK, Lubomír E. Velká Morava a Franská ř́šse. K otázce vzájemných politických vztahů. In Historické štúdie, 1963, roč. 8, s. $129-180$. 
štitúcií (Pasovské biskupstvo) voči Moravanom, ${ }^{56}$ no naddunajský slovanský priestor reálne tvoril odlišnú právnu sféru.

Avšak pomerne ambivalentne sa uvedená skutočnost’ prejavuje na príklade prvého známeho utečenca na Morave, Albgisa. Tento bližšie neznámy človek bol podla nariadenia mohučskej synody, konanej v roku 852, poslaný do vyhnanstva (in exilium missus) kvôli únosu manželky istého Patrika. Cudzoložník Albgis podla znenia prameňa uniesol ženu vydatú za iného muža do najvzdialenejšieho konca Ríše (ad extremos fines regni), čiže práve na územie Moravanov, za čo bol následne formálne odsúdený do vyhnanstva. ${ }^{57}$ Vzhl'adom na to, že podla cirkevných kánonov mu bol uložený dohromady sedemročný trest, počas ktorého sa mal kajat' za svoje previnenie, môžeme predpokladat', že legálne stanovenie dĺžky obdobia jeho vyhnanstva súviselo s časom stanoveného pokánia.

Pri Albgisovom úteku k Moravanom si treba uvedomit', že previnilec hladal a zrejme aj našiel azyl v krajinách mojmírovského panstva, pretože tu sa nachádzal „na najvzdialenejšom konci“ východofranskej ríše. ${ }^{58}$ Tým pádom Albgis utiekol s unesenou manželkou na Moravu z čisto praktických dôvodov, ked’že sa potreboval(i) dostat' mimo dosahu franskej súdnej moci. Podla rozsudku, ktorý bol vynesený na mohučskej synode však trest za únos manželky a asi aj za vraždu ${ }^{59}$, čiže sedemročné vyhnanstvo a pokánie, mal nadobudnút' platnost' aj v moravskej oblasti. Je preto pomerne nejednoznačné určit', nakol'ko Albgisa franská právna sankcia reálne postihla. Hypoteticky však možno predpokladat', že si svoj trest „odpykával“ na Morave. Existuje však možnost', i ked' text rozsudku to explicitne neuvádza ani inak neimplikuje, že Albgis mohol byt' Moravanmi neskôr po svojom úteku vydaný naspät' do Franskej ríše, a tak by počas rozhodnutia z mohučskej synody previnilec už bol v sfére domáceho práva. $V$ tomto prípade však pravdepodobnejšie išlo o rozsudok v jeho neprítomnosti; Albgisa tak zastihol už v dobrovol'nom exile na Morave, ktorý sa následne mal stat’ aj jeho trestným pokáním.

Okrem Albgisovho prípadu existuje ešte jedna zmienka, ktorá dokresl'uje charakter výkonu súdnej praxe v pohraničí bavorského a moravského územia. V privilegiálnej listine východofranského krála Arnulfa z roku 888 vystavenej pre svojho ministeriála Heima, ktorý bol podriadený markgrófovi Aribovi, sa uvádza, že do východnej marky zjavne bežne prichádzali l'udia z moravského kniežatstva so zámerom rozsúdit' svoje

56 Asi najzretel'nejšie sa to prejavuje v známej formulácii autora Fuldských análov, ktorá priamo odrážala oficiálnu východofranskú dvorskú optiku tvrdením, že moravskí Slovania sa snažili odpadnút' od ríše (defectionem molientes), a preto následne musel král' L'udovít II. Nemec zasiahnut' a usporiadat' pomery na hraniciach svojho královstva (ordinatis et iuxta libitum suum conpositis rebus). Ann. Fuld. ad a. 846, s. 36. Bližšie pozri: LYSÝ 2014 , s. 171-182; LYSÝ, Miroslav. „Sclavos Margenses defectionem molientes“. Mojmírovci medzi suverenitou a závislost'ou. In KISELYOVÁ, Zuzana et al. (eds.) Míl'niky práva v stredoeurópskom priestore, 1. čast'. Bratislava : Právnická fakulta Univerzity Komenského, 2013, s. 96-102.

57 Concilium Moguntinum §11. In MGH : Additamenta ad Capitularia Regum Franciae orientalis (d'alej CRF), č. 249, s. 189: „Albgis, qui uxorem Patrichi publice auferens ad extremos fines regni duxit in rudem adhuc christianitatem gentis Maraensium et crimine adulterii acclesiam Christi diffamavit, communi consilio decernimus, ut iussu regis in exilium missus iuxta sacrorum canonum statuta penitentiam pleniter agat, id est: III annos cum pane et aqua et leguminibus atque holeribus, excerptis precipuis festivitatibus, et postea IV annos alios per singulas ebdomadas III dies similiter abstineat et III quadragesimas, nisi infirmitatis nimia hoc ilium prohibeat ita inplere..."

58 K Albgisovmu prípadu pozri: CIBULKA, Jozef. Velkomoravský kostel v Modré u Velehradu a začátky křest'anství na Moravě. Praha : Nakladatelství Československé akademie věd, 1958, s. 279-281.

59 Rozsudok o Albgisovi je súčast’ou článku pojednávajúcom o prečine vraždy (De homocidio). Concilium Moguntinum §11, č. 249, s. 189. 
spory. V listine sa píše, že osoby, ktoré by prišli z ríše Moravanov (de Marauorum regno) kvôli dovolávaniu sa práva, má rozsudzovat' Heimo zo svojho titulu sudcu (iudex) alebo jeho právny zástupca (advocatus eius), pritom ako konečná odvolávacia inštancia je určený markgróf Aribo. ${ }^{60} \mathrm{Aj}$ ked' správa zretel'ne neuvádza Moravanov, ale len niektorých l'udí (aliquis) z „ríše Moravanov“, možno sa domnievat', že v poslednej tretine 9. storočia v mojmírovskom panstve pôsobil istý okruh osôb, ktorý považoval bavorský právny systém a miestnu súdnu prax, ktorá bola pravdepodobne dôslednejšie reglementovaná ako na Morave, za bežný spôsob usporadúvania právnych záležitostí. Prelínanie a akulturáciu rôznych zložiek obyvatel'stva, predovšetkým však mocenských elít, môžeme čiastočne sledovat' aj pri dalších správach o vyhnancoch a exulantoch zo západných regiónov.

Pät' rokov po Albgisovom úteku našiel exil u moravského kniežata Rastislava syn jedného z českých kniežat Slavitach (Sclavitago), ktorého vyhnali z hradu jeho otca po útoku ríšskeho vojska. Situáciu následne využil jeho brat, ktorý sa, naopak, vrátil z exilu od srbského kniežat'a Čestibora. ${ }^{61}$ Pramene mlčia o následnom osude vyhnaného Slavitacha, kedže d'alšie správy o kontaktoch Moravanov s Čechmi sa objavujú až od 70. rokov 9. storočia v súvislosti s vládou Svätopluka. ${ }^{62}$ Avšak podla Kristiánovej legendy, spísanej zrejme na konci 10. storočia, ${ }^{63}$ aj české knieža Bořivoj kvôli nechuti svojich súkmeňovcov prijat' krest'anstvo a hrozbe zabitia utiekol k Svätoplukovi a Metodovi. ${ }^{64}$ Eventualita Bořivojovho úteku k moravskému panovníkovi je založená najmä na povesti o krste českého kniežat’a, ktorú zaznamenal mních Kristián so značným časovým odstupom, preto je historicitu tejto udalosti t’ǎké vylúčit’ alebo potvrdit. ${ }^{65}$

Fuldské anály podrobnejšie informujú o d’alšom vysoko postavenom človeku, ktorý utiekol do Rastislavových dŕžav z bavorského pohraničia a d'alej pôsobil ako vojvoda v moravskom prostredí. Korutánsky gróf Gundakar ${ }^{66}$ si v roku 863, vd’aka prebehnutiu od rebelujúceho Karlomana k jeho otcovi L’udovítovi II. Nemcovi, vyslúžil hodnost' prefekta Východnej marky. ${ }^{67}$ Nepoznáme presné dôvody a okolnosti, ktoré viedli správcu východofranského pohraničia k hladaniu politického azylu na Morave. Nie je vylúčené, že jeho útek k Moravanom súvisel s vypuknutím povstania vo Východnej marke v roku 866, ktoré organizoval královský syn L'udovít III. (876 - 882) a do ktorého sa zapojil aj moravský Rastislav ${ }^{68} \mathrm{~V}$ dôsledku podozrenia $\mathrm{z}$ organizovania vzbury a spojenectva s Rastislavom bol už franský gróf Verinhar v roku 865

60 Diplomata 44. In MMFH III, s. 57: „Et is forsan de Marauorum regno aliquis causa iustitiae supervenerit, si tale quidlibet est quod ipse Heimo vel advocatus eius corrigere nequiverit, iudicio eiusdem comitis potenter finiatur."

61 Ann. Fuld. ad a. 857, s. 47.

62 Pozri: TřEŠTíK 1997, s. 297, 312-313; STEINHÜBEL 2012, s. 68-76.

63 Podrobne: KALHOUS, David. Legenda Christiani and Modern Historiography. Leiden ; Boston : Brill, 2015.

64 Christiani monachi Vita et passio sancti Wenceslai et sancte Ludmile ave eius. In MMFH II, s. 172.

65 Pozri TřĚ̌TíK 1997, s. 336-337.

66 K rodovému pôvodu a postaveniu Gundakara vo Východnej marke pozri: MITTERAUER, Michael. Karolingische Markgrafen im Südosten. Wien : Verlag der Österreichischen Akademie der Wissenschaften, 1963, s. $175-178$.

67 Ann. Fuld. ad a. 863, s. 56-57.

68 Ann. Fuld. ad. a. 866, s. 64-65; Annales Bertiniani ad. a. 866, In MMFH I : Annales et chronicae, Třetí revidované a rozšírené vydaní. BARTONKKOVÁ et al. (eds.). Koniasch Latin Press : Praha, 2019, s. 55-56. 
obžalovaný pred král'om a následne zbavený svojej funkcie. ${ }^{69}$ Niekedy v tomto období boli zosadení zo svojich grófskych postov aj Uton a Berengar. ${ }^{70}$ Možno sa preto domnievat', že Gundakar ako prefekt Východnej marky, ktorá bola jedným z ohnísk celého povstania, nezostal pri revolte proti franskej moci verný královi, ale zrejme patril k mocenskej klike bavorských a korutánskych elít, ktoré hl'adali spojenectvo u moravských kniežat. Ak sa Gundakar skutočne spolčil s Rastislavom už počas povstania v roku 866, je prirodzené, že sa po jeho rýchlom potlačení ${ }^{11}$ uchýlil k Moravanom ako renegát. V turbulentnom roku 869 sa už definitívne zdržiaval severne od Dunaja a so zbraňou v ruke na čele moravských oddielov hájil mojmírovské záujmy proti svojmu niekdajšiemu seniorovi Karlomanovi, ktorého v minulosti zradil kvôli dohode s jeho otcom L’udovítom II. Nemcom. Omilostený Karloman však po rokoch získal príležitost' vykonat' pomstu na svojom bývalom vazalovi, neváhajúcom „mnohými krivými prísahami a l'stivými úskokmi stat'sa mnohokrát neverný královi L’udovítovi a jeho synom"72 Gundakar v boji s Karlomanovými vojskami padol a obšírny spôsob, akým franský analista vykresl'uje jeho zabitie dáva jasne tušit', že odpadlíctvo vysokého franského hodnostára, ktorý „opustiac vlastného pána, pridal sa na stranu Rastislavovu“ vnímali ríšsky predstavitelia so značným zadost'učinením. ${ }^{73}$ Farbistý opis posledných chvíl' vzbúreného grófa, prehovárajúceho k moravskému vojsku a vzývajúceho sv. Emeráma, ktorý ho kvôli vierolomnosti oslabí v boji a vydá napospas franským mečom, ako aj zmienka o d’akovných oslavách Boha a sviatočnom vyzváňaní Regensburských zvonov na pokyn L'udovíta Nemca, výrečne ilustruje postoj, aký prechovávali reprezentanti východofranského královského dvora voči osobám, ktoré sa rozhodli postavit’ na odpor najvyššej autorite, či dokonca prebehnút' k inému vládcovi.

\section{Vilhelmovci a Mojmírovci vo vyhnanstve}

Začiatok sedemdesiatych rokov 9. storočia sa v krajinách moravsko-bavorského pohraničia niesol v znamení zásadných mocenských poryvov. Zajatie a zosadenie Rastislava a väznenie jeho synovca Svätopluka v roku 870 viedlo ku krátkodobému pripojeniu mojmírovskej dŕžavy k územiam Východnej marky. Moravské územia boli z poverenia Ludovíta II. Nemca zverené do správy markgrófom Viliamovi a Engelšalkovi. ${ }^{74} \mathrm{~V}$ dôsledku Svätoplukovho úspešného návratu na Moravu, a po jeho bezprostrednom znovunadobudnutí kniežacej vlády nad Moravanmi, prišli vo

69 Ann. Fuld. ad a. 865, s. 63.

70 Ann. Fuld. ad a. 866, s. 64-65: „Werinharium quoque, Utonem et Berengarium comites a patre suo [L'udovítom Nemcom] depositos."

71 Annales Bertiniani ad a. 866, s. 56: „Quam praecedens, in brevi rebellantes sine conflictu domat et hostem nondum pene promotum domi residere mandavit."

72 Ann. Fuld. ad. a. 869, s. 68.

73 Ann. Fuld. ad. a. 869, s. 68: „Gundakar vassallus Carlmanni, qui multis periuriis et dolosis machinationibus Hludowico regi eiusque filiis saepenumero extitit infidelis et proprium dominum [de]relinquens ad Rastizen defecerat, contra patriam [more Catilino] dimicare volens occisus est. Hic Carlmanni ducibus ad locum certaminis propinquantibus dixisse fertur ad eos, quibus a Rastizo erat praelatus: ,Pugnate fortiter vestram patriam tuentes; ego enim in hoc certamine vobis proficuus non ero, quoniam sanctus Emmerammus cete rique sancti, ina quorum reliquiis Hludowico regi filisque illius fidem me servaturum [esse] iuravi, [meum clipeum et hastam tenentes] mea brachia iusum premunt et me undique constrictum quasi loris ligatum retinent, ita et nec manum quidem ad os mittere praevaleam.' Dum haec infelix loqueretur, nostris supervenientibus occubuit, Domino illi infidelitatis suae condignam mercedem retribuente. Quod cum regi relatum fuisset, omnes in commune Deum laudare signis etiam cunctarum in Reganesburg aecclesiarum concrepantibus pro interitu hostis extincti praecepit."

74 K tomu pozri: TŘEŠTÍK 2001, s. 194-200. 
vojenských zrážkach o život obaja východofranskí správcova z vilhelmovského rodu. ${ }^{75}$ Príslušníci tohto rodového klanu nadobudli významné mocenské postavenie v bavorských krajinách ešte niekedy v prvej tretine 9. storočia. ${ }^{76}$ Po smrti Viliama a Engelšalka nezískali dedičnú správu nad Východnou markou ich synovia, ani iní Vilhelmovci, ale král' L'udovít II. Nemec dosadil v roku 871 ako markgrófa Ariba. ${ }^{77}$ Nový správca pohraničia bol po čase konfrontovaný s dedičnými nárokmi mladých Vilhelmovcov. Nespokojní uchádzači vyzvali králom dosadeného markgrófa, aby im prenechal svoju pozíciu a územie spravované ich otcami, pretože inak ho násilne zosadia. Aribo v snahe nájst' mocenskú zábezpeku proti neodbytným ašpirantom na markgrófsku funkciu sa obrátil so žiadost’ou o pomoc na moravské knieža. Svätopluk a Aribo uzavreli dohodu o politickej podpore, pričom podmienky si do značnej miery akiste diktoval práve moravský knieža, keď̌̌e na Moravu bol poslaný ako rukojemník samotný markgrófov syn Isanrik. ${ }^{78}$ Synovia Viliama a Engelšalka nakoniec naplnili svoje hrozby a niekedy v roku 882 vyhnali Ariba z Východnej marky. ${ }^{79}$ Týmto násilným činom začal vyše desat'ročie vlečúci sa konflikt, ktorého počiatočná fáza medzi rokmi 882 - 884 je v historiografii označovaná ako Vilhelmovská vojna (Wilhelminer War). Ohnisko bojových stretov ležalo práve v moravsko-bavorskom pohraničí a na pomedzí Blatnohradu, ktorý po Kocelovej smrti mocensky ovládal korutánsky vojvoda a neskorší východofranský král' Arnulf. Počas dlhotrvajúcich bojov medzi odbojnými Vilhelmovcami a straníkmi Ariba a moravského kniežatáa Svätopluka sa nešetrilo vraždami a úkladmi. Až okolo roku 893 skončila séria prenasledovaní, útekov a krvných pômst, pričom vilhelmovský klan zostal na konci bojov značne zdecimovaný a zostávajúci preživší sa museli uchýlit’ do politického exilu, ${ }^{80}$ pritom aspoň čast' bývalých pokrvných nepriatel'ov nakoniec našla dočasný azyl práve na Morave.

Ostáva otázne, kam sa na istý čas uchýlil markgróf Aribo po tom, ako ho v roku 882 Vilhelmovci pozbavili úradu a vypudili z Bavorska. Franský analista uvádza jedine okolnost', že králom ustanovený správca pohraničia bol nečestne vyhnaný (inhonorifice expellebant), no nezmieňuje sa o mieste, kam Aribo utiekol. Je možné, že krátkodobý azyl našiel bud' u svojho seniora, východofranského krála Karola III. Tučného, alebo, čo je ovela reálnejšie, práve na území moravského kniežat’a, s ktorým uzavrel spojenectvo a na ktorého panstve sa zdržiaval ako rukojemník jeho syn Isanrik. Z Fuldských análov sa síce dá dozvediet', že král' Karol III. „čoskoro vrátil spomenuté

75 Ann. Fuld. ad. a. 871, s. 73-74; Annales Bertiniani ad. a. 871. In MMFH I, s. 59-60.

76 ZEHETMAYER, Roman. Rakouské Podunají kolem roku 900. In MACHÁČEK, Jiří - WIHODA, Martin (eds.) Pád Velké Moravy aneb Kdo byl pohřben v hrobu 153 na Pohansku u Břeclavi (d'alej Pád Velké Moravy). Praha : Nakladatelství Lidové noviny, 2016, s. 79-80. K pôvodu a postaveniu Vilhelmovcov pozri: MITTERAUER 1963, s. 172-188.

77 Annal. Fuld. ad. a. 884, s. 110: ,...non vero esset honor illorum filiis redditus, Arbo in comitatum domno rege concedente succesit."

78 Annal. Fuld. ad. a. 884, s. 110-111: „Quod praedictorum virorum pueruli illorumque propinqui in contrarium accipientes vel vertentes dixerunt alterutrum fieri, vel Arbonem comitem, si non recederet de comitatu parentum suorum, vel se ipsos ante faciem gladii morituros. Hoc experimento Arbo concussus amiciciam iniit cum Zuentibaldo duce Maravorum gentis firmataque inter illos foedera filium suum obsidem fieri non tardavit."

79 Annal. Fuld. ad. a. 884, s. 111: „...comitem a rege constitutum inhonorifice expellebant comitatumque illis in usum usurpaverunt."

80 BOWLUS, Charles. Wilhelminer und die Mährer. In Zeitschrift für Bayerische Landesgeschichte, 1973, roč. 36, s. 761-775; MACLEAN, Simon. Kingship and politics in the late Ninth Century. Charles the Fat and the end of the Carolingian Empire. Cambridge : Cambridge University Press, 2003, s. 136-143; ZEHETMAYER 2016, s. 80. 
grófstvo Aribovi“" ${ }^{\text {i1 }}$ no text neobsahuje detaily o mieste, kde tento oponent Vilhelmovcov reálne našiel útočisko po vypudení z funkcie comes terminalis. $V$ tejto súvislosti je vel'mi pravdepodobné, že Aribo bol po Gundakarovi už druhý markgróf, ktorý z politických dôvodov hladal azyl na Morave..$^{82}$ Nasvedčovala by tomu skutočnost', že bezprostredne na to, ako Vilhelmovci vyhnali Ariba, Svätopluk s ním potvrdil dohodnuté priatel'stvo a prísahu (amicitie et iuramenti, quae cum Arbone iniit pepigitque) a rázne zaútočil proti vilhelmovským pozíciám v rakúskom Podunajsku. ${ }^{83} \mathrm{~S}$ istou dávkou špekulácie preto možno vyslovit' domnienku, že samotný Aribo po svojom vyhnaní v roku 882 na krátky čas pôsobil v moravskej oblasti, odkial' smeroval hlavný útok proti znepriateleným Vilhelmovcom. Žiaden prameň však takýto predpoklad priamo nepotvrdzuje.

Mocenská situácia, ktorá sa vyprofilovala na konci Vilhelmovskej vojny, mala značne odlišný ráz oproti rozloženiu síl spred dvoch rokov. Aribo si bezpečne udržal funkciu markgrófa aj po roku 887, ked' zasadol na východofranský královský stolec jeden z jeho hlavných oponentov z predošlých bojov - korutánsky vojvoda Arnulf. Nový král' vzišiel z radov bavorskej aristokracie, pričom Vilhelmovci sa ešte v začiatkoch konfliktu zverili do jeho služieb. ${ }^{84}$ Skončenie neutíchajúcich bojov musel podnietit’ až cisár Karol III., ked’ sa v roku 884 počas stretnutia na hore Comiano pokúsil zmierit’ obe znepriatelené strany. Podla bavorských analistov boli za hlavných vinníkov rozbrojov považovaní práve Vilhelmovci, ${ }^{85}$ no Karol III. zrejme presvedčil Svätopluka, aby pristal na mier, ako aj na určité odškodnenie svojich súperov. ${ }^{86}$ Pramene nás informujú, že v časoch skončenia bojov už niektorí zo starých Svätoplukových nepriatelov z vilhelmovského klanu pobývali v novom exile na Morave. Moravania tak medzi seba, podobne ako po iné roky, prijali exulantov z radov východofranských provinčných elít. V roku 893 vilhelmovec Engelšalk II. dokonca uniesol Arnulfovu nemanželskú dcéru a utiekol s ňou práve na Moravu. Samotná závažnost' protiprávneho skutku nebránila v neskoršom uzmierení tohto „muža mladíckej odvahy“ (iuvenili audatia vir) s králom Arnulfom. Navyše z poverenia panovníka, proti ktorému sa iba nedávno previnil, následne získal vytúžený titul markgrófa východného pohraničia. ${ }^{87}$ Engelšalkova kariéra v ríšskej správe však nemala dlhé trvanie. Kvôli rozporom s bavorskou aristokraciou sa dostal do nemilosti významného okruhu l'udí a po predvolaní do Regensburgu bol bez vedomia krála Arnulfa oslepený. Následne popravili aj jeho príbuzného Viliama, pričom dôvodom hrdelného trestu mali byt' kontakty s moravským kniežat’om Svätoplukom..$^{88}$

Vilhelmovský exil na Morave neskončil štastne. V dôsledku prenasledovania ostatných rodových príslušníkov bol na Morave zabitý d’alší vyhnanec, Viliamov brat Ru-

81 Ann. Fuld. ad. a. 884, s. 111: „Qui mox, prout antea tenuit, Arboni praedictum comitatum reddidit..."

82 Rovnako uvažoval: ZAVADIL, Ondřej. Dopis markrabího Ariba králi Arnulfovi. In Mediaevalia Historica Bohemica, roč. 11, č. 1, 2007, s. 13.

83 Ann. Fuld. ad. a. 884, s. 111.

84 Ann. Fuld. ad. a. 884, s. 112: "recesserunt statueruntque fieri homines Arnolfi.“

85 MACLEAN 2003, s. 138-139.

86 WIHODA, Martin. Druhý život mojmírovských knížat. In Pád Velké Moravy, s. 153.

87 Ann. Fuld, ad. a. 893, s. 122.

88 Ann. Fuld, ad. a. 893, s. 122. 
odpert. Podla fuldského analistu údajne na pokyn samotného Svätopluka. ${ }^{89}$ Nielen Ruodpert, ale aj jeho družina a mnohí neznámi, alebo pre franského autora menej významní exulanti (cum allis quam plurimis) našli v krajinách moravských Slovanov svoju smrt'. A to aj napriek tomu, že im tu bolo poskytnuté útočisko. Ťažko povedat', do akej miery sa podarilo týmto l'ud’om z vonkajšieho bavorského, respektíve korutánskeho prostredia integrovat' do cudzej spoločnosti. Vyhnanci a utečenci však prúdili oboma smermi aj po Svätoplukovej smrti v roku 894. Krátko predtým, ako prepukol mocenský zápas medzi Mojmírom II. a Svätoplukom II., synmi zosnulého moravského kniežat’a, Moravania žiadali král'a Arnulfa „, záujme zachovania mieru“, aby neprijímal vyhnancov, ktorí sa k nemu uchylovali na úteku z mojmírovských dŕžav.$^{90}$ Kto boli spomenutí vyhnanci či utečenci, nie je celkom jasné. V minulosti sa uvažovalo o „frankofilských straníkoch“ Svätopluka II., prípadne sa verilo, že správa sa môže skôr vztahohovat' na české kniežatá, ktoré dva roky predtým pretrhli politické zväzky s mojmírovským kniežatstvom. ${ }^{91}$ Je však možné predpokladat', že posolstvo Moravanov z roku 897 sa týkalo hierarchicky vyššie postavených osôb z bavorského pohraničia, ktoré podobne ako po minulé roky hladali prechodný či trvalý azyl v moravských krajinách.

Poodhalenie konkrétnych dôvodov „emigrácie“ týchto exules nie je na základe dostupnej pramennej bázy vôbec jednoduché. Napriek tomu ostáva zrejmé, že mojmírovská Morava bola vítaným útočiskom predovšetkým pre vypudené bavorské elity. Jeden z týchto vyhnancov sa ešte aj začiatkom 10 . storočia posledný raz vynára z kronikárskych správ. Švábska svetová kronika doplnená o zápisy Hermanna z Reichenau z 11. storočia, vychádzajúca zo správy fuldského analistu, poslednýkrát uvádza meno vyhnanca, ktorý istý čas pôsobil ako exulant na Morave. ${ }^{92}$ Išlo pritom opät' o vysoko postaveného príslušníka východofranskej pohraničnej aristokracie. Bavorský gróf (Noricus comes) Isanrik sa za panovania Mojmíra II. dostal do exilu na Moravu, pričom sa po skončení d'alšieho z radu bavorsko-moravských konfliktov následne zmieril s králom L'udovítom IV. ${ }^{93}$ Isanrik vystupoval na konci 9. storočia proti autorite cisára a krála Arnulfa, ním podnecovanou revoltou sa zaoberajú aj Fuldské anály, ktoré tiež uvádzajú okolnosti jeho úteku k Moravanom. ${ }^{94}$ Či už išlo o vyhnania z politických alebo trestno-právnych dôvodov, alebo jednoducho o pragmatické úteky do bezpečného prostredia v slovanskom pohraničí na periférii franského vplyvu, územia Moravanov boli pomerne bežným útočiskom mocenských elít z východofranskej ríše.

Záverom treba spomenút', že aj niektorí z Mojmírovcov, podobne ako príslušníci mnohých iných rodov včasného stredoveku, museli zrejme v určitom momente odíst' do vyhnanstva. Ak zohladníme, že Svätopluka II. v roku 899 spoločne s jeho l'ud'mi

89 Ann. Fuld, ad. a. 893, s. 122: „Frater quoque eius cum Maravanis exul delatiscens insidioso consilio ducis cum aliis quam plurimis interfectus est."

90 Ann. Fuld., ad. a. 897, s. 130: ,...advenientibus ibidem ad eum Maravorum missis, qui pro pace constituenda, ne exules eorum profugi reciperentur, ab imperatore flagitant..."

91 Pozri komentár Lubomíra Havlíka: In MMFH I : Annales et chronicae. BARTOŇKOVÁ, Dagmar et al. (eds.). Praha : Státni pedagogické nakladatelství, 1966, s. 123 poznámka 3.

92 Ann. Fuld. ad. a 901 (Herimanni Augiensis Chronicon). In MMFH I, s. 111.

93 Ann. Fuld. ad. a 901 (Herimanni Augiensis Chronicon), s. 111: „Eodem anno Moymarius dux Marahensis et Isanricus Noricus comes, qui ad ipsum transfugerat, cum Ludovico rege pacificati sunt."

94 Ann. Fuld. ad. a. 899, s. 133. 
(suum populum) oslobodila bavorská výprava zo zajatia, kam ho uvrhol brat Mojmír II., a Bavori ho následne aj odviedli do končín ich vlasti (in fines patriae sue abduxerunt), ${ }^{95}$ je potom celkom reálne uvažovat’ o mojmírovskom exile. Akýsi Svätopluk zo vznešeného rodu koncom augusta roku 898 nadobudol darom od cisára Arnulfa sídelné majetky v Korutánsku, ${ }^{96}$ pritom prvá donačná listina bola spísaná iba pol roka predtým, než došlo k oslobodeniu Svätopluka II. z moravského zajatia. Napriek odlišným názorom na pôvod Svätopluka z listín cisára Arnulfa ${ }^{97}$ je viac než len pravdepodobné, že jeho urodzený pôvod (vir progenie bonae nobilitatits exortus) svedčí o príslušnosti k mojmírovskému rodu. Vzhl'adom na politické okolnosti a fuldským analistom zaznamenaný rok odchodu Svätopluka II. do bavorských krajín (899) asi nemožno bezpečne potvrdit', že išlo o jedného zo synov najmocnejšieho moravského panovníka. Avšak možnost', že urodzený muž obdarovaný v lete 898 Arnulfom skutočne bol identický so Svätoplukom II. tiež nie je neprípustná. ${ }^{98}$ Altaišské pokračovanie Fuldských análov totiž uvádza k roku 898 bavorskú výpravu vedenú najvyššími predstavitel'mi Východnej marky - grófmi Liutpoldom a Aribom - ktorá prišla pomôct' zrejme na osobnú žiadost'(!) jednej zo súperiacich strán. ${ }^{99}$ Existuje preto možnost', že brat Mojmíra II. a syn Svätopluka I. už v roku 898 podnikol cestu do Východnej marky kvôli snahe nájst' spojencov. ${ }^{100}$ Nie je vylúčené, že mladší syn kniežat'a Svätopluka, teda muž (či skôr ešte mladík) z význačného rodu, mohol byt’ už počas prebiehajúceho bratského sporu obdarovaný cisárom Arnulfom menšími majetkami v Korutánsku. V každom prípade, Svätopluk, ktorý od konca 9. storočia vystupuje vo viacerých listinách ako svedok a vazal Liutpolda, môže byt' pokojne stotožnený s viac alebo menej významným Mojmírovcom, ktorý v dôsledku nástupníckych sporov ušiel za Dunaj a bezprostredne nato začal pôsobit’ v radoch korutánskych elít. ${ }^{101}$

Navyše je asi zjavne omylom domnievat’ sa, že zánik „Vel’kej“ Moravy, ktorého príčiny historiografia najčastejšie hladá v dobyvačnom úsilí mad’arských kmeňov, ${ }^{102}$ bol aj faktickým zánikom panovníckeho rodu. Mužskí príslušníci mojmírovského vládnuceho klanu v skutočnosti dovedna nevykrvácali pri obrane svojej krajiny, ale prinajmenšom čast' rodovej línie našla nové pole pôsobnosti v rakúskom Podunajsku. Moderné bádanie opatrne predpokladá, že Mojmírovci mohli byt’ v dôsledku politických otrasov na

95 Ann. Fuld. ad. a. 899, s. 133.

96 Diplomata 51. In MMFH III, s. 64-65.

97 Pozri komentár Lubomíra Havlíka: Diplomata 51. In MMFH III, s. 64, poznámka 312; K tomuto záhadnému Svätoplukovi, ktorý pôsobil ako vazal salzburského grófa Liutpolda pozri najnovšie: WIHODA 2016, s. 155-157. Porovnaj MĚŘ́́NSKY, Zdeněk. Morava na úsvitě dějin. Brno : Muzejní a vlastivědná společnost, 2011, s. 593-596. 98 K tomu pozri komentár Davida Kalhousa a Zdeňka Měřínskeho: In MMFH I (2019), s. 107, poznámka 629.

99 Ann. Fuld. ad. a. 898, s. 131-132: „Tunc vero rex imperator ista sciens marchiones suos, Liutbaldum scilicet et Arbonem comitem, una cum ceteris fidelibus suis parti, quae ad se spem ac confugium habuit, auxilium ad eorum liberationem protectionemque Bawarios suos primates transmisit."

100 Túto možnost' opatrne pripúšt’al Lubomír Havlík. Pozri jeho komentár: In MMFH I (1966), s. 125, poznámka 5. 101 WIHODA 2016, s. 155.

102 K novším interpretačným modelom a názorom na príčiny pádu Vel'kej Moravy pozri podnetne: MACHÁČEK - WIHODA 2016. Porovnaj: ŠTEFAN, Ivo. Great Moravia, Statehood and Archaeology. The 'Decline and Fall' of One Early Medieval Polity. In MACHÁČEK, Jiř́ - UNGERMAN, Štefan (eds.) Frühgeschichtliche Zentralorte in Mitteleuropa. Bonn : Habelt Verlag, 2011, s. 333-354. So zretel'om na východnú čast' moravského kniežatstva pozri najnovšie: KÖNIG, T. Nitrianski Slovania a zánik Vel'kej Moravy. In CHUDZIŃSKA, Barbara - WOJENKA, Michał - WOŁOSZYN, Marcin (eds.) Od Bachórza do Światowida ze Zbrucza. Tworzenie się słowiańskiej Europy w ujęciu źródłoznawczym. Księga jubileuszowa Profesora Michała Parczewskiego. Kraków ; Rzeszów : Uniwersytet Jagielloński ; Uniwersytet Rzeszowski, 2016, s. 181-187. 
začiatku nového veku vyhnaní, prípadne nútení odíst' z krajín, nad ktorými kedysi držali moc. ${ }^{103}$

Svedčia o tom predovšetkým početné pramenné správy, ktoré na začiatku 10. storočia v Bavorsku zmieňujú osoby s dedičnými menami Mojmírovcov ako významných svedkov právnych pokonaní. Medzi rokmi 924 a 935 sa v salzburskom prostredí objavujú v katalógu arcibiskupa Odalberta comes Mojmír a nobilis vir Svätopluk. ${ }^{104}$ Martin Wihoda presvedčivo predostrel, že obaja spomenutí aktéri mohli byt' viac či menej vzdialení príbuzní, pochádzajúci z rovnakých rodových štruktúr, ktorých príslušníci ešte pred niekol'kými rokmi koncentrovali vo svojich rukách moc na Morave. Dokonca je možné, že prinajmenšom jeden z mojmírovských predákov sa v prvej polovici 10. storočia pokúsil o návrat z bavorského exilu do oblasti starého sídla v Pohansku pri Břeclavi. ${ }^{105} \mathrm{~V}$ súvislosti so zánikom mojmírovskej moci asi tiež nemožno pustit' zo zretel'a možnost', že vládnuci rod mohol na začiatku 10. storočia z rozličných príčin stratit' v očiach Moravanov panovnícku legitimitu. Následkom oslabenia mocenskej pozície by tak došlo $\mathrm{k}$ „vypovedaniu charizmatickej zmluvy“ medzi dovtedy sakralizovaným a privilegovaným pokolením potomkov Mojmíra (či iného mýtizovaného predka reprezentujúceho dedičnú moc) a spoločenstvom Moravanov. ${ }^{106}$ Tristný zánik Vel'kej Moravy, nad ktorým lamentovali niektorí autori 10. storočia, by tak do výraznej miery znamenal práve pád Moravy mojmírovskej. Azda d’alšie bádanie dokáže bližšie ozrejmit' okolnosti a dôvody stojace za skutočnost'ou, že niektorí držitelia rodových mien panovníkov kedysi mocnej Moravy našli dočasné pôsobenie v oblastiach bavorského pohraničia.

103 HAVLÍK, Lubomir E. Morava v 9. a 10. století. K problematice politického postavení, sociálni a vládni struktury a organizace. Praha : Academia, 1978, s. 94-102; WIHODA 2016, s. 151-160.

104 K rodovým menám Mojmírovcovm zmieňovaných v Codex Odaleberti a k okolnostiam mojmírovského exilu: WIHODA 2016, s. 153-160.

105 WIHODA 2016, s. 156-160.

106 Pozri: WIHODA. Martin. Morava v době knížecí. 906 - 1197. Praha : Nakladatelství Lidové noviny, 2010, s. 91-93.

Cituj:

HARVÁT, Matej. Úteky, vyhnanci a renegáti na moravsko-bavorskom pohraničí v 9. storočí. In Forum Historiae, 2019, roč. 13, č. 2, s. 40-58. ISSN 1337-6861. DOI: https://doi.org/10.31577/forhist.2019.13.2.3

Mgr. Matej Harvát

Oddelenie stredovekých dejín

Historický ústav SAV

P. O. Box 198, Klemensova 19, 81499

Bratislava

Slovenská republika

matej.harvat@savba.sk 